University of Nebraska - Lincoln

DigitalCommons@University of Nebraska - Lincoln

$1-2012$

\title{
The Driving Forces Of Land Change In The Northern Piedmont Of The United States
}

Roger F. Auch

U.S. Geological Survey's Earth Resources and Observation Science Center, auch@usgs.gov

Darrell E. Napton

South Dakota State University, darrell.napton@sdstate.edu

Steven Kambly

U.S. Geological Survey's Eastern Geographic Science Center, kambly@usgs.gov

Thomas R. Moreland Jr.

U.S. Geological Survey's Eastern Geographic Science Center, tmorelan@usgs.gov

Kristi L. Sayler

U.S. Geological Survey's Earth Resources and Observation Science Center, sayler@usgs.gov

Follow this and additional works at: https://digitalcommons.unl.edu/usgsstaffpub

Auch, Roger F.; Napton, Darrell E.; Kambly, Steven; Moreland, Thomas R. Jr.; and Sayler, Kristi L., "The Driving Forces Of Land Change In The Northern Piedmont Of The United States" (2012). USGS Staff -Published Research. 587.

https://digitalcommons.unl.edu/usgsstaffpub/587

This Article is brought to you for free and open access by the US Geological Survey at DigitalCommons@University of Nebraska - Lincoln. It has been accepted for inclusion in USGS Staff -- Published Research by an authorized administrator of DigitalCommons@University of Nebraska - Lincoln. 


\title{
THE DRIVING FORCES OF LAND CHANGE IN THE NORTHERN PIEDMONT OF THE UNITED STATES
}

\author{
ROGER F. AUCH, DARRELL E. NAPTON, STEVEN KAMBLY, \\ THOMAS R. MORELAND JR., and KRISTI L. SAYLER
}

\begin{abstract}
Driving forces facilitate or inhibit land-use / land-cover change. Human driving forces include political, economic, cultural, and social attributes that often change across time and space. Remotely sensed imagery provides regional land-change data for the Northern Piedmont, an ecoregion of the United States that continued to urbanize after 1970 through conversion of agricultural and forest land covers to developed uses. Eight major driving forces facilitated most of the land conversion; other drivers inhibited or slowed change. A synergistic web of drivers may be more important in understanding land change than individual drivers by themselves. Keywords: driving forces, ecoregions, land-use change, Northern Piedmont, urbanization.
\end{abstract}

$\mathcal{T}_{\mathrm{s}}$

he Northern Piedmont is an integral part of Megalopolis, the corridor of U.S. coastal cities and land use that Jean Gottmann identified in 1961 as a new type of human settlement. Gottmann described the new types of social and economic interaction that result when the activities of growing, adjacent cities overlapped and began to commingle. Suburbanization and exurbanization based on the automobile permitted middle-class families to live in low-density suburbs and exurban locations. The rapid growth of urban-oriented development included higher per capita land consumption, which, in Megalopolis, was unable to convert land to urban uses as rapidly as reforestation was reclaiming farmland (Gottmann 1959). The northern Megalopolis remains a relevant region, for research continues to document its changing form and/or show how Gottmann's idea helps form a base theory for continued study of evolving, present-day urbanization (Morrill 2006; Short 2007; Vincino, Hanlon, and Short 2007; Lang and Knox 2009).

The geographical core of Megalopolis is in the Northern Piedmont, which stretches from the New Jersey suburbs of New York City to central Virginia and encompasses the western portions of metropolitan Philadelphia, Baltimore, and Washington, D.C., as well (Figure 1). It forms a transitional zone between the older, slowly growing metropolitan areas of northern Megalopolis and the rapidly growing areas of the Washington, D.C., Metropolitan Area (Vincino, Hanlon, and Short 2007), and it is also a transition zone between the flatter coastal plain to the east and the more mountainous regions to the west and north. An undulating plateau, it is dissected by a number of rivers that generally flow eastward and

Mr. Auch is a research geographer at the U.S. Geological Survey's Earth Resources and Observation Science Center (eros), Sioux Falls, South Dakota 57198; [auch@usgs.gov]. Dr. NAPton is a visiting scientist at ERos and a professor of geography at South Dakota State University, Brookings, South Dakota 58007; [darrell.napton@sdstate.edu]. Mr. Kambly and Mr. Moreland are geographers at the U.S. Geological Survey's Eastern Geographic Science Center, Reston, Virginia 20192; [kambly@usgs.gov], [tmorelan@usgs.gov].Ms.SAYLER is a physical scientist at EROs; [sayler@usgs.gov]. 


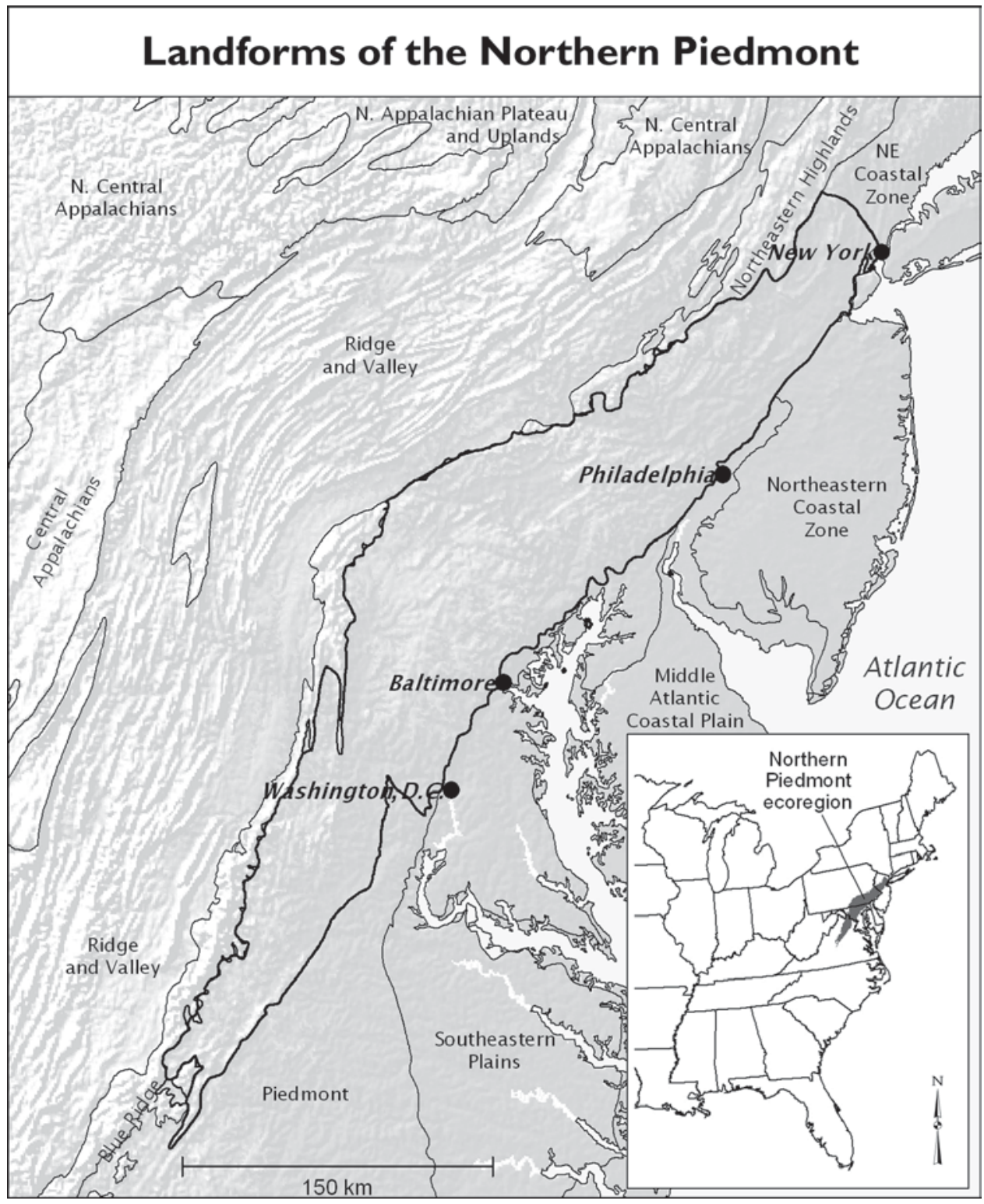

FIG. 1-The Northern Piedmont's landforms in shaded relief, with the location of major cities. The Northern Piedmont ecoregion is outlined in black. (Cartography by Kristi Sayler)

southeastward to the Atlantic Ocean via various estuarine bays. One of the oldest and historically most productive farming areas in the United States is in the middle of the Northern Piedmont: The farmland of southeastern Pennsylvania is the only large area of good soils along the Eastern Seaboard (Hart 1991a).

Our focus is on this region during a time of continued suburban growth and extensive, low-density growth that occurred in exurban areas. We chose to assess 
land changes in the Northern Piedmont in the decades after the publication of Megalopolis (Gottmann 1961). Questions we sought to answer included whether farmland abandonment continued to outpace urban development and to what extent farmland may have been converted directly to developed-urban-land uses before farmers abandoned it. In particular we sought to measure which general classes of land cover were converted and the driving forces behind those changes.

Although each land-cover change is local, landowners often base their landchange decisions on their perception of regional and national forces. They make land-use decisions that will allow them to adapt to or take advantage of changing personal and societal situations. The information and motivations that landowners use to make land-use decisions are human driving forces that include political, economic, cultural, and social attributes (Meyer and Turner 1994). Among the many specific driving forces are public-land policies, economic events, and population changes. Not only are driving forces important because humans now dominate the earth's ecosystems (Ojima, Galvin, and Turner 1994; Vitousek and others 1997), but each decision to change or maintain a parcel's land use or land cover has cumulative regional, national, and even global consequences as well as local ones. A better knowledge of how and why owners make land-use decisions lead to a better understanding of regional climate modifications, ecosystem changes, and biogeochemical cycle alterations, while guiding policy development to help society adapt to climate change, protect biodiversity, and limit land degradation (CGCR 1999).

We used samples of Landsat remotely sensed imagery to document and measure Northern Piedmont land-cover changes that occurred between 1973 and 2000. The imagery was interpreted to provide information about ten general types of land cover and their associated changes at a 6o-meter resolution. Fieldwork, socioeconomic data, and existing literature provided a geographical and intellectual context to land changes. This research is part of the U.S. Geological Survey (USGs) Land Cover Trends project to estimate land changes in the conterminous United States (Napton and Loveland 2004). The sampling was based upon U.S. Environmental Protection Agency ecoregions, which have been useful for organizing and interpreting land changes (Omernik 1987; Gallant and others 2004; Napton and others 2010; Sleeter and others 2011).

Our methods for determining driving forces that either facilitated or inhibited land-use change-in this ecoregion, mostly new development; that is, urban and built-up, nonagricultural uses-consists of weaving Northern Piedmont examples from the literature together with some empirical data to show the complex web affecting individual land changes-or lack of changes, with drivers that inhibited land-use change. David Theobald detailed the difficulties determining the extent of mixed land uses and land covers at or beyond the urban fringe that are mostly scale related (2001). A direct causal effect of specific driving forces facilitating or inhibiting change for a particular parcel of land is difficult. In this article we tell 
the general story of land change in an important and continually urbanizing region of the United States.

\section{Contemporary Land-Cover Trends in the Northern Piedmont}

We estimated land-cover change in the Northern Piedmont by sampling Landsat remotely sensed images of ten randomly selected 20-by-20-kilometer sample blocks (Figure 2). Manual interpretation of satellite imagery-derived land-use / landcover change in 1973, 1980, 1986, 1992, and 2000 enabled us to create maps used to calculate statistically rigorous estimates of land area and change types for each time interval. ${ }^{1}$ The goal was to capture total land-cover change in the ecoregion within a 1 percent margin of error at an 85 percent confidence level (Loveland and others 2002). Estimates of individual land-cover types represent how well our sampling captured their spatial distributions across the ecoregion. In the Northern Piedmont the sampling caught the amount of land-cover change within our desired goal, but estimates of individual land-cover types had higher amounts of uncertainty because of their spatial variability within the ecoregion.

In 1973 the predominant land-cover categories in the Northern Piedmont were: agriculture, 37.7 percent $( \pm 9.4)$; forest $36.9( \pm 7.2)$ percent. Developed areas also covered a substantial portion of the Northern Piedmont's landscape, at an estimated $22.7( \pm 11.7)$ percent. $^{2}$ These three categories made up almost the entire ecoregion. Other land-cover types, such as water, wetlands, and mining, occupied less than 3 percent of the area.

The overall amount of land-cover change was generally steady for the first three time intervals, ranging from $1.3( \pm 0.3)$ to $1.5( \pm 0.5)$ percent per interval but increasing to 2.6 ( \pm 0.6$)$ percent between 1992 and 2000. The last interval had the highest change, at $0.3( \pm 0.1)$ percent when annualized to compensate for unequal time lengths but only slightly higher than the other three intervals, which averaged around $0.2( \pm 0.1)$ percent of the ecoregion a year. We emphasize that these are average annual estimates of land-cover change and that the actual amount of change could have varied from year to year within each time interval.

The overall "footprint" of change was $6.2( \pm 1.1)$ percent between 1973 and 2000. This is less than the cumulative total of the four time intervals, however, because some land changed more than once during the study period. Some forest parcels may have been clear-cut but later returned to forest or were developed. These parcels occupied the same space, so they counted for overall change only once.

The two most prevalent land-cover changes during the entire 1973-2000 study period were conversions from agriculture to developed and from forest to developed. Other leading land-use / land-cover changes included agriculture to forest and a forest harvest rotation (forest to mechanically disturbed-trees cleared from the land-and mechanically disturbed to forest). These four leading land changes accounted for the great majority $-81.4-86.8$ percent-of the total change for each of the four time intervals. 


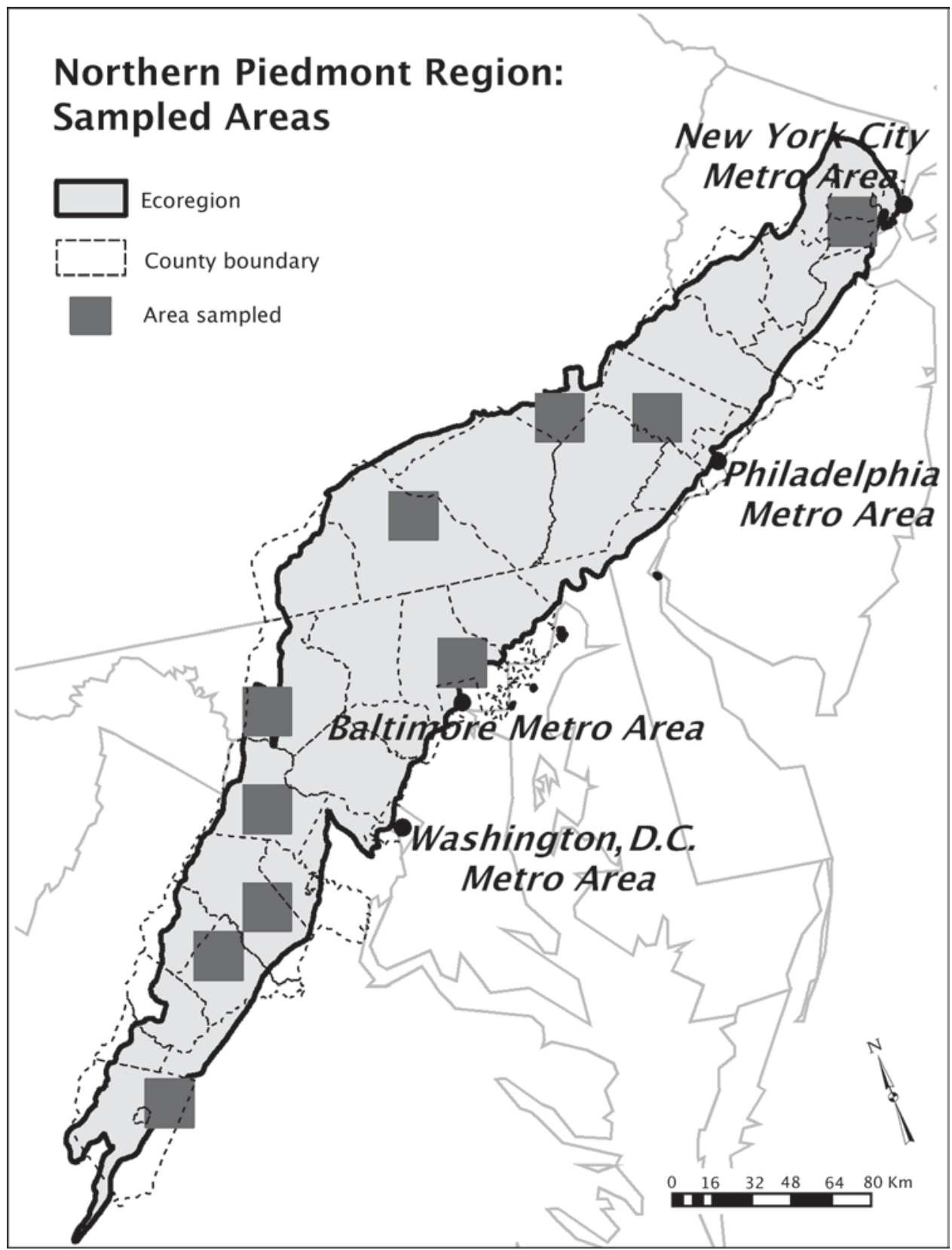

FIg. 2-Locations of usgs Land Cover Trends project sample blocks in the Northern Piedmont ecoregion. (Cartography by Kristi Sayler)

The two largest land-cover conversions were particularly important because developed land is difficult and expensive to change to another, more natural land cover. Some portions of the ecoregion, especially those in the major metropolitan areas, were heavily urbanized at the beginning of the study period, thus preclud- 
THE GEOGRAPHICAL REVIEW

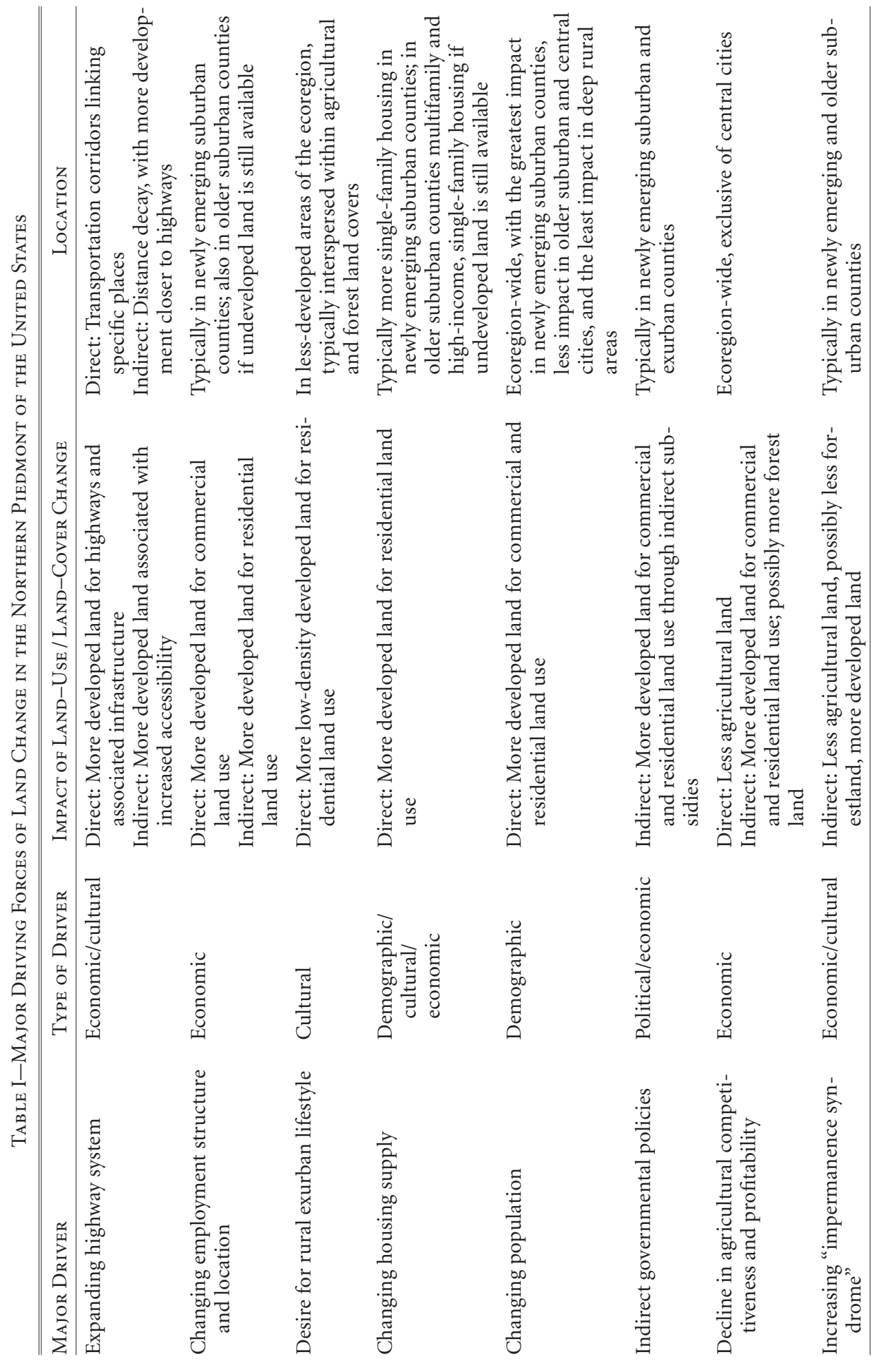


ing any appreciable change to other land-cover types. The amount of area represented by the major unidirectional changes (agriculture to developed and forest to developed) was approximately $1,331( \pm 467)$ square kilometers, or $4.4( \pm 1.5)$ percent, of the ecoregion. The unidirectional change from agriculture or forest to developed accounted for approximately 65 percent of the total change in the Northern Piedmont during the four time intervals between 1973 and 2000.

The land-cover conversions that occurred between 1973 and 2000 resulted in a $4.6( \pm 1.1)$ percent increase in the amount of developed land and a $3.4( \pm 1.2)$ percent decrease in the amount of agricultural land. The percentage of forested land held relatively steady over much of the study period but ultimately declined $1.5( \pm 0.5)$ percent from 1973 to 2000 . These changes equated to an estimated increase of 1,396 $( \pm 343)$ square kilometers of developed land, a decrease of 1,015 ( \pm 348$)$ square kilometers of agricultural land, and a decrease of $446\left( \pm_{141}\right)$ square kilometers of forested land. The changes in other land-cover categories were minor.

The Northern Piedmont's overall decline in forest land cover during the study may further substantiate what other authors have found using Land Cover Trends project data at the larger scale of the eastern United States and in other urbanizing ecoregions (Drummond and Loveland 2010; Sohl and Sohl, in press); namely, that the "forest transition theory" of continued reforestation after a low point dominated by agricultural land use no longer holds true (Mather 1992; Mather and Needle 1998). Agriculture to forest was the third leading type of change during the first two intervals (1973-1980 and 1980-1986), thus almost countering the forest-to-developed change during this time. Agriculture-to-forest change dropped off substantially during the 1992-2000 interval, and forest-to-developed increased. This accounted for much of the overall forest decline in the ecoregion.

\section{DRIVING ForCES}

\section{CHANGE-FACILITATING DRIVERS}

We identified eight primary driving forces that promoted land change (Table I). Some of these had components that were unique to the ecoregion, such as the suburbanization of federal agencies around the Washington, D.C., metropolitan region. Others were more national in scale, such as the expanding highway system, changing household demographics, and federally backed home mortgages. Four of these drivers fit primarily into a single category: "changing employment structure and location" as an economic driving force, for example, and "desire for rural exurban lifestyle" as a cultural driving force. Other, more complex drivers fit multiple categories: The expanding highway system greatly impacts economic activity, but it also stems from Americans' propensity to use personal motor vehicles. Indirect governmental policies obviously fit into the political driving forces category, but they usually result in some sort of economic gain for the people who benefit from them, so they are also an economic driver. Most land changes resulted from multiple drivers and scales that came together in specific times and places. 
New highways increased access, both immediately preceding and during the study period, to much of the Northern Piedmont. National and state policies tended to expand the highway system, but their effect tended to be felt at the regional and local scales. The building of interstate beltways around the central cities and the interweaving of other federal and state highways around them created new centers of economic development. The Interstate 695 beltway around Baltimore had gained the nickname "Golden Horseshoe" by the early 1980 os because of the recent commercial development around it (DiLisio 1983, 195-196). The intersections of multiple major highways became the foundation of new "suburban nucleations" or "edge cities" such as where Interstates 287 and 78 meet in Somerset County, New Jersey (Erickson and Gentry 1985; Garreau 1991).

Less access to major highways and greater distance to major metropolitan areas may be among the reasons why specific counties had the lowest populations in the ecoregion in 2000. ${ }^{3}$ Adams County, Pennsylvania, had no four-lane highways bisecting it east-west and only one four-lane road going north-south (Figure 3). The five Virginia counties and independent cities between Manassas and Charlottesville-both of which had interstate-highway access-also had no eastwest four-lane highways and only a meandering, segmented four-lane highway going north-south. These Virginia counties were the least populated in the ecoregion. Hunterdon County, New Jersey, had only two major roads to the west across the Delaware River, and fast access out of the county to the east used three multilane highways. Interstate 78 , completed during the study period, increased the county's access to and from the greater New York / Northern New Jersey Metropolitan Area. This was reflected in the fact that, between 1970 and 2000, population growth was greater in Hunterdon County than the other counties just mentioned.

The nation's changing economic structure facilitated land change in the Northern Piedmont. Manufacturing became less dependent on railroads and more on trucking, and new factory architecture favored single-story buildings with large footprints. The urban fringe had more abundant and affordable land for new construction and became the preferred location, especially near major roads or intersections (Lewis 1995, 43, 52-55). Meanwhile, service-based employment was replacing manufacturing as the dominant jobs sector. Manufacturing had concentrated in the older urban counties or in older smaller cities (USCB 1973). By 1990, professional and related services were the dominant employment sector in the Northern Piedmont (Jakle and Wilson 1992, 57-79, 86-92; UsCB 1993; Miller 1995, 261-262).

Most of the increases in the service sectors were in the old or newly suburban counties adjacent to or one county removed from the central cities (Figure 4). Recently built commercial "edge cities" or corridors along major highways became the locations for many of these job types (Fulton 1986; Garreau 1991). Wilbur Zelinsky described the growing suburban and exurban landscapes of southeastern Pennsylvania as "governed by the tertiary and quaternary sectors of the economy and their sociocultural fallout" (1995, 141). 


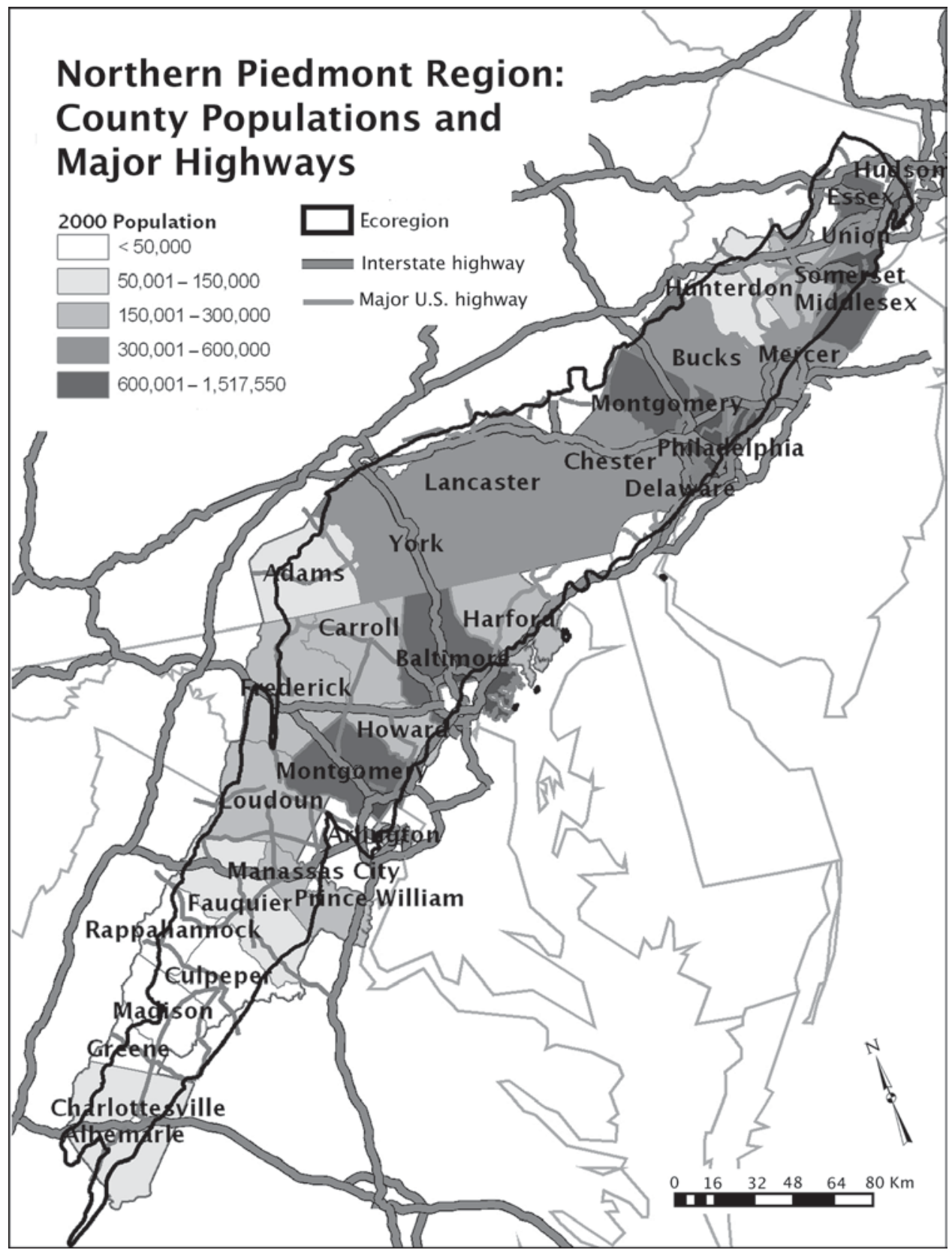

FIg. 3-The Northern Piedmont ecoregion in 2000: county populations and major highways. Source of population data: UsCв 2003. (Cartography by Kristi Sayler)

Overall, the Northern Piedmont gained 1,557,185 new jobs between 1970 and 2000 (USCB 1973; usBLS 2001). Older suburban counties-Middlesex, in New Jersey; Bucks and Montgomery, in Pennsylvania; Baltimore and Montgomery, in Maryland-accounted for 48 percent of this new employment. Newer suburban counties 
-Somerset, in New Jersey; Chester, in Pennsylvania; Howard, in Maryland; Loudoun and Prince William, in Virginia-tallied up another 30 percent of the new jobs.

The Northern Piedmont has a long history of exurban living. The expanding highway network fostered this desire to live in rural surroundings but work in a metropolitan area. The result was additional developed land in traditionally rural areas. John Herbers described Loudoun County, Virginia, as "a place noted for its big houses and riding stables on ten acre [4-hectare] lots but again, most who live there are tied one way or another to the Washington economy" $(1986,76)$. The close proximity of the major metropolitan areas to each other favored the creation of exurban conditions in other counties, such as Howard County, Maryland, where residents could access multiple metropolitan areas. An exurban lifestyle that incorporated even more rural flavor was hobby farming, in which exurbanites engaged in some sort of agricultural practice but received limited, if any, economic gain from it (Layton 1980; Daniels 1986) (Figure 5).

The changing status of the ecoregion's housing supply was yet another influence on land change. The number of occupied housing units in the Northern Piedmont increased by 1,238,938 between 1970 and 2000, two-thirds of that gain in the previously mentioned core group of older and newer suburban counties (GeoLytics 1999; USCB 2003). National demographic changes required more housing units to shelter the same number of people (Gober 1981). In the Northern Piedmont the size of an average household fell from 3.2 persons in 1970 to 2.7 persons in 2000 (GeoLytics 1999; UsCB 2003). The desire for a newly constructed home many times led to locations on or away from the urban periphery, where more affordable land was usually available.

Strict, local-scale land-use policies could resonate upward to a regional scale and help drive this situation. In Montgomery County, Maryland, an older subur-

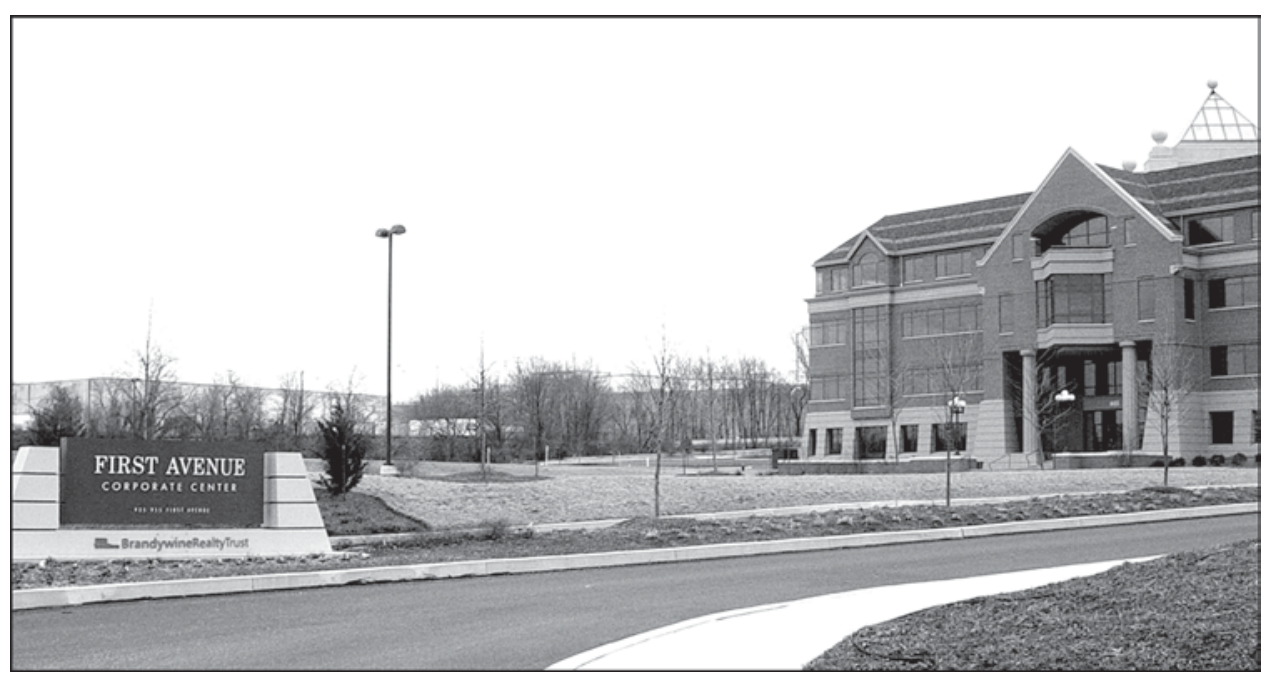

FIG. 4-Commercial real estate in a new business park, King of Prussia, Pennsylvania, approximately 25 kilometers from downtown Philadelphia. (Photograph by Roger Auch, March 2004) 


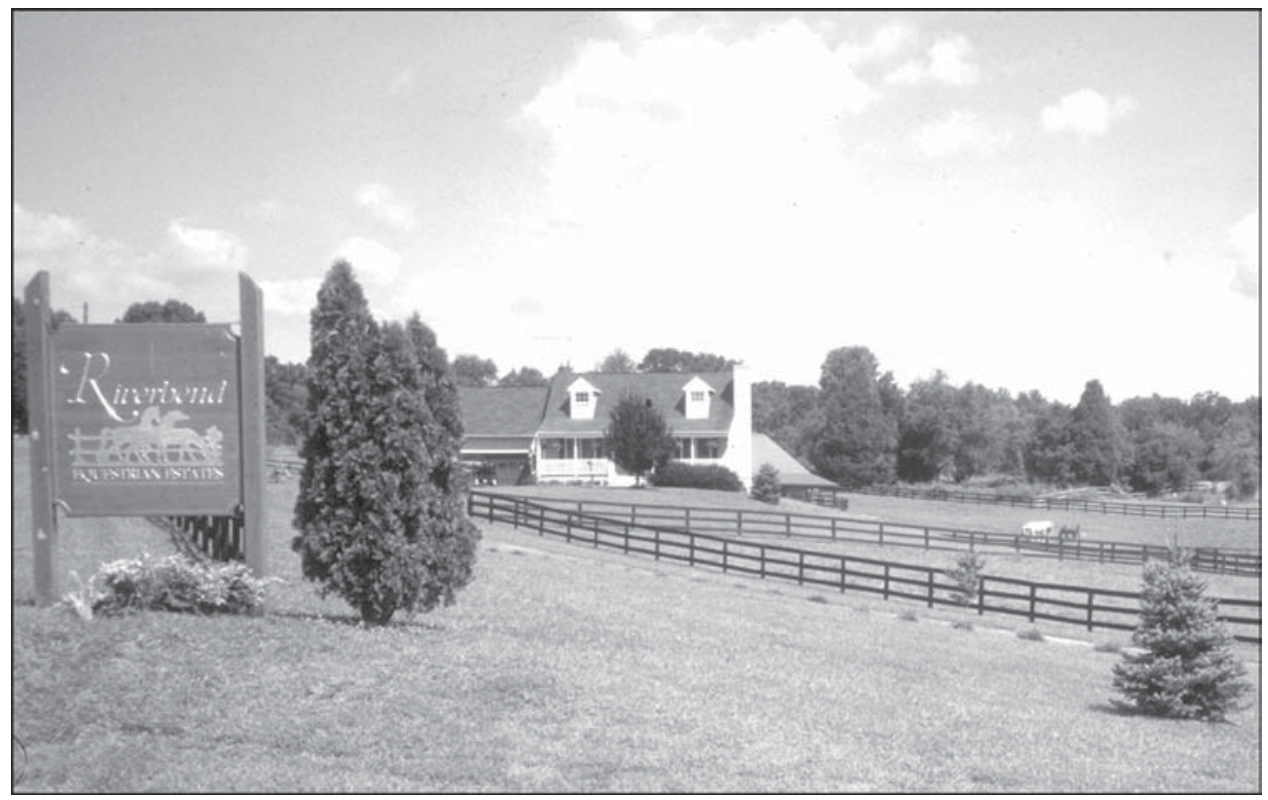

FIG. 5-A residential subdivision that caters to people who own horses in Culpeper County, Virginia. (Photograph by Roger Auch, August 2001)

ban county, certain planning districts or individual municipalities were placed into "temporary" development moratoriums if their perceived growth was seen as adding to the area's traffic congestion. In response, developers formed "road clubs" to provide the needed infrastructure, and housing construction continued. Builders then passed the costs on to home buyers by specializing in higher-priced houses. Many people who could not afford a home in Montgomery County moved across its boundaries to live but continued to drive to and work in the county (Levinson 1997). This "spillover" around the major metropolitan areas helped cause the search for affordable new housing to widen geographically (Morrill 1992) (Figure 6).

A changing population also facilitated change. Between 1970 and 2000 the population of the Northern Piedmont increased by 1,913,544 to 11,623,238 (GeoLytics 1999; USCв 2003). Intraregional migration tended to be from the urban cores outward into peripheral areas; interregional and foreign migration usually was the reverse. In Maryland the older suburban counties of Montgomery and Baltimore had net out-migration to neighboring counties during the 1980 . The same counties, however, had the highest net in-migration from interregional and foreign sources during the same time, thus continuing to gain population through migration along with natural increase of more births than deaths. Metropolitan Washington, D.C., in particular, became a focus for regional foreign immigration (Goldstein 1995, 1-6, 33-39, 58, 60, 62, 64, 66, 70, 72; Friedman and others 2005).

Direct and indirect governmental policies and actions many times led to landuse changes and spanned all scales. By indirectly subsidizing the cost of development land uses federal programs such as those involving highways, government-backed 


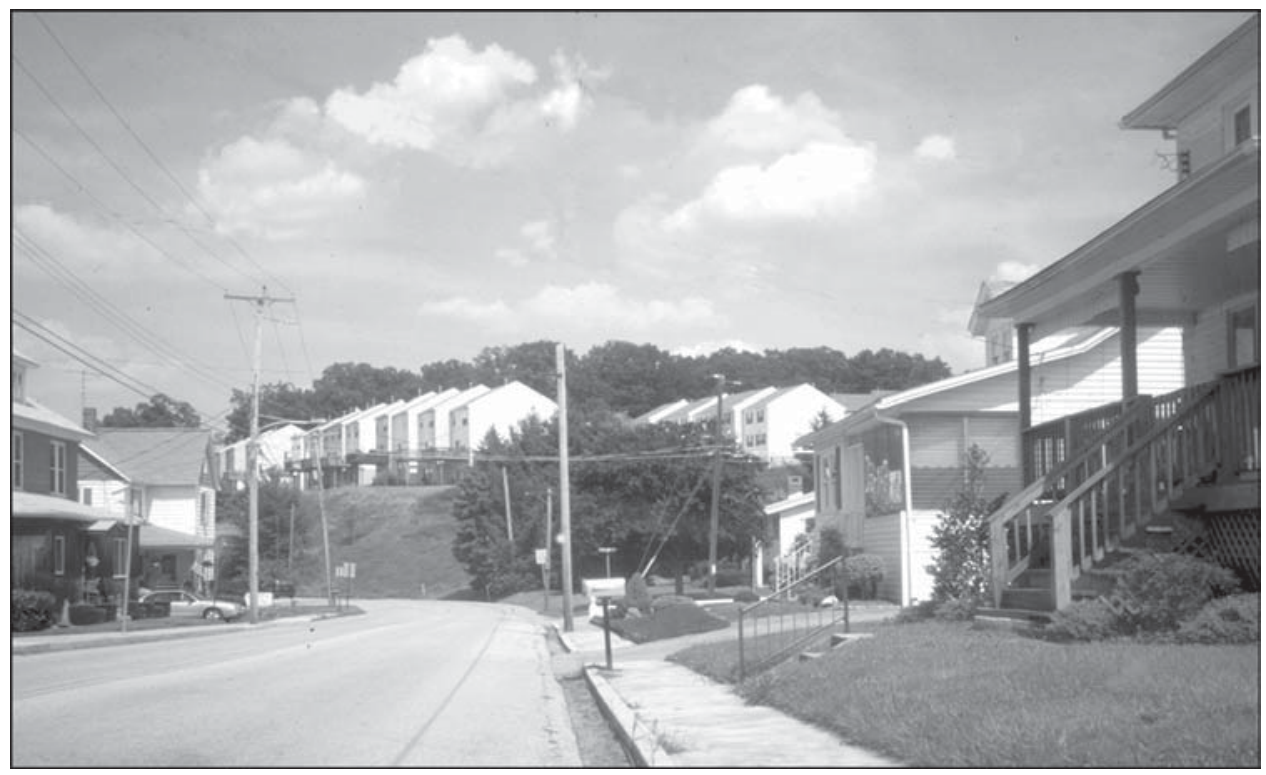

FIG. 6-New homes line the hills in New Freedom, Pennsylvania. Residents can drive approximately 6 kilometers to Interstate 83, and from there it is less than 25 kilometers to York or 40 kilometers to metropolitan Baltimore. (Photograph by Roger Auch, August 2001)

home mortgages, tax credits for new commercial buildings, or automobiles helped bring development to places where it was previously limited. Whereas taxes on motor-vehicle fuel directly paid for much of the new road construction, the new highway or upgraded roadway spurred new development in the area. Similarly, lending institutions and developers made a profit from federally backed home mortgages, and the availability of more easily financed home purchases allowed the indirect conversion of agricultural or forest land into residential land use (Jackson 1985, 191-195, 203-218; Herbers 1986, 166-167; Hanson 1992; Hartmann and Goldstein 1994, 306).

State governments also encouraged land change by giving economic development loans to communities on the metropolitan periphery. An example of this situation was what transpired in northeastern and north-central New Jersey during the 1980 os, where 56 percent of the state's economic development loans went to the "physically extensive and middle-income towns and townships that offered large amounts of vacant land to developers" (Danielson and Wolpert 1992, 500). Local governments subsidized land-use change by competing with one another to attract new businesses that they hoped would increase their tax bases (Moe and Wilkie 1997, 10-11; Blum 1998). Private developers many times became the main agents of change on the local level (Frankel and Pae 1997).

The erosion of regional agricultural viability within the ecoregion helped bring about land change. The Northern Piedmont has a long history of catering to urban markets, especially in specialized commodities. Ecoregion producers lost some of their competitive advantages with the construction of a high-speed national high- 
way system and the increasing economies of scale within U.S. agribusiness (Schertz 1979, 271-272; Hart 1991b). Agricultural land-use conversion became easier when competitiveness with other agricultural regions decreased. The low profitability in more common agricultural products at the national scale also played a role in change. Local governments could preserve farmland but had little control over national policy and markets (Giordano and Schnidman 1979). A Germantown, Maryland, farmer quoted in the Washington Post stated, "They can preserve all the land they want, but it won't be saved if agriculture isn't profitable” (Fehr 1997).

An increased "impermanence syndrome" facilitated changes in traditional rural land uses. The ability to farm or grow timber using older conventional methods was negatively affected as the land base became more fragmented and friction increased between these uses and urbanization (Lopez, Adelaja, and Andrews 1988; Kelsey and Singletary 1996; Daniels 2000). The growing isolation of individual farms and commercial forest plots resulted in a decrease of the supporting infrastructure and long-term reinvestment (Smith 1999; Wear and others 1999). The increasing numbers of landowners selling out to development in many places within the ecoregion were reflected in surveys of local farmers, the majority of whom believed they could make more money by selling their land for development than by continuing to farm (Fehr 1997; Smith 1999, 289-291) (Figure 7). The "impermanence syndrome" is a long-standing land-use theory of urbanizing areas within the United States (D. Berry 1978; Lopez, Adelaja, and Andrews 1988; Tavernier and Tolomeo 2004; Adelaja, Sullivan, and Hailu 2011), but it may be more complex than first envisioned (Lockeretz, Freedgood, and Coon 1987). The dynamic nature

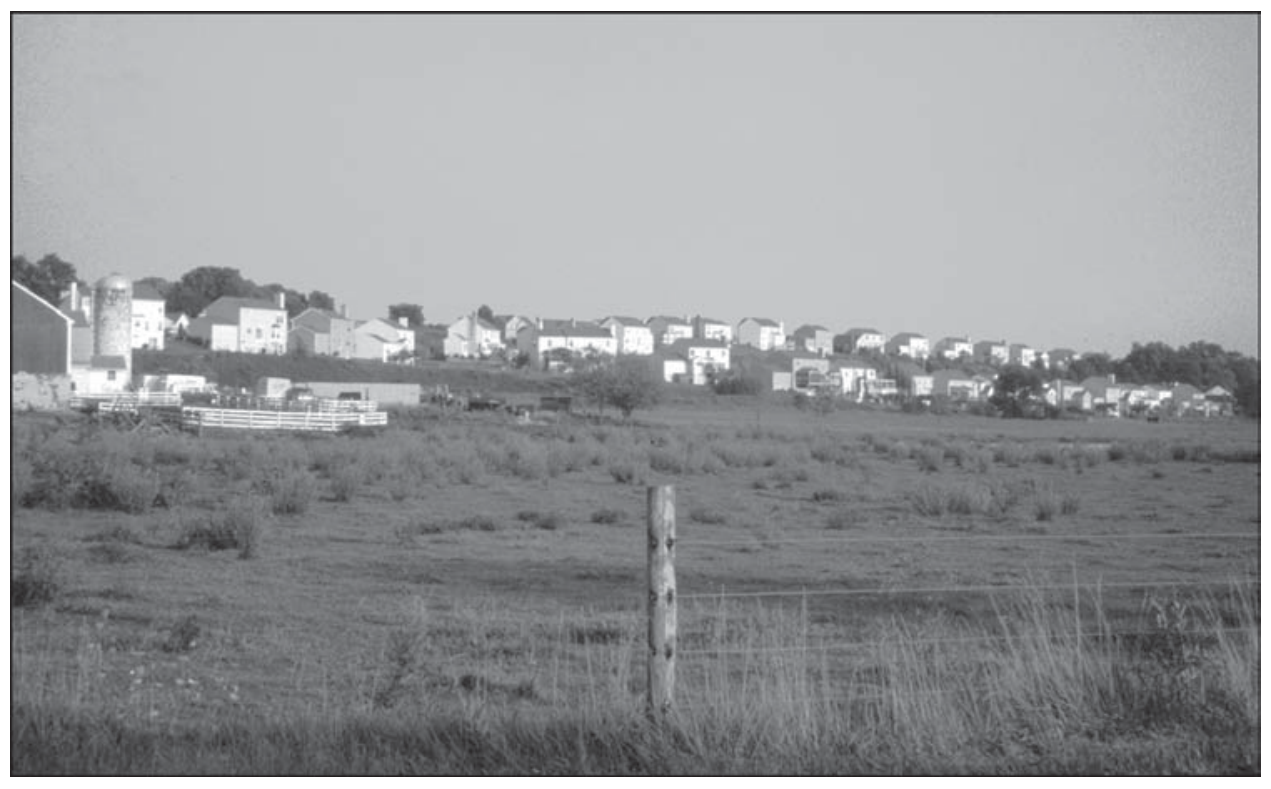

FIG. 7-The interface of development and agriculture land uses in Frederick County, Maryland. (Photograph by Roger Auch, August 2001) 


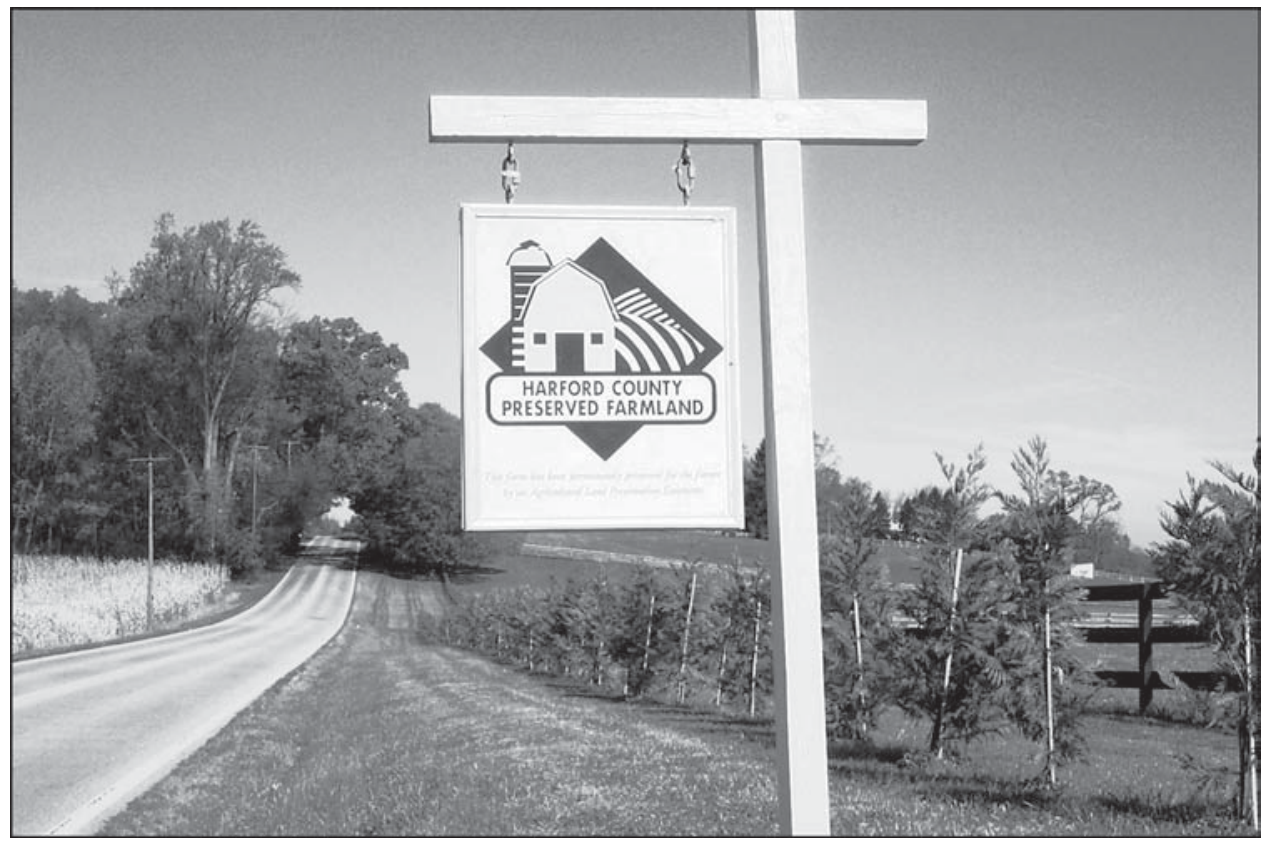

FIG. 8-Land in Harford County, Maryland, preserved from development. (Photograph by Thomas R. Moreland Jr., summer 2003)

of the impermanence syndrome makes it more of a driver of change than a mere symptom of change (Adelaja, Sullivan, and Hailu 2011).

Multiple driving forces, then, many times influenced individual land-use/landcover changes in the Northern Piedmont. A hypothetical example could be a new rural subdivision surrounded by farmland and forest located near a multilane highway thirty minutes from the metropolitan periphery. A majority of the homeowners found employment in various service-sector occupations located in an "edge city" next to the intersection of several highways. The corporations that the homeowners work for had relocated to their present site after constructing buildings that had been given tax credits for new commercial real estate. The land where the subdivision was located, formerly pasture, became available for development when a local farmer decided to eliminate his milk cows because of increased competition from ever-larger regional and national dairies and diminishing local support infrastructure in the area. This example illustrates the "web" of driving forces affecting a single land-use change. Change did not result from a single driver in a linear fashion; instead, multiple drivers tended to reinforce one another.

\section{CHANGE-INHIBITING DRIVERS}

Some driving forces worked to maintain or slow land conversion. Factors identified as inhibitors of change or stabilizers of current land use in the Northern Piedmont included governmental policies, organized opposition to change, the presence of "reserved lands," and long-standing traditions of productive farming and cul- 
tural landscapes. Almost all of these drivers initiated at the regional and local scales, although several existed at a national scale.

During the 1970s concerns arose as to whether, because of increased development, the United States had enough cropland to meet future demands for food and fiber (Batie and Healy 1980). By the 1990s governmental initiatives to counter unrestrained growth in the Northern Piedmont, sometimes called "sprawl," became increasingly popular as outlying areas began to suffer from the negative externalities of pollution, loss of open space, and traffic congestion. These initiatives, often referred to as "smart growth," used various mechanisms to promote development in existing neighborhoods and conserve rural landscapes on the edges of metropolitan areas (Gustanski and Squires 2000; Wells 2001; SPC 2004; NJDEP 2010). Maryland's Rural Legacy Program, launched in 1997, had a more focused goal of farmland preservation and natural-resource protection (Lynch 2009). Local county governments also often initiated open space- or farmland-preservation policies. Several counties in the Northern Piedmont had aggressive farmlandpreservation programs and consistently ranked among the top counties nationally in the number of farm hectares preserved. In 1997 the Northern Piedmont had six out of the nation's top ten counties that together had preserved 58,700 hectares (Fehr 1997) (Figure 8).

Sometimes local, and occasionally national, opposition to specific development proposals became a land-change inhibitor that resulted in the abandonment or modification of these projects. Residents and other concerned citizens often perceived the new development as a threat to the current land use, such as the integral vistas associated with historic sites. In 1986 a developer purchased land adjacent to the Manassas National Battlefield Park in the northern Virginia suburbs of Washington, D.C. The public outcry against this development resulted in federal purchase of the property and its addition to the existing park (Garreau 1991, 373-388, 402-422). In the same general area as the Manassas battlefield the Walt Disney Company proposed a historic theme park in 1994. Opponents of this project were concerned about the potential negative impacts from increased traffic, air pollution, and off-site development associated with a 1,200-hectare recreation park and its projected six million annual visitors. Under pressure, Disney abandoned the project within a year (Moe and Wilkie 1997, 3-32).

A more local example, also in Virginia, was when residents of Loudoun and Fauquier counties opposed the initial plans for widening state Route 50 because they feared that the upgraded road would destroy the rural character of their local communities. The residents formed an advocacy group, proposed an alternative plan-one they perceived would result in less land change-and worked with state and local governments to implement it (R50CC 2011).

Reserved lands-lands owned by federal, state, or local governments-may form barriers to land change. Parks, refuges, monuments, and other governmental lands are generally protected from development and not subject to the same economic pressures as are areas outside park boundaries. Reserved lands are one of the few 
examples of a national-scale change inhibitor that operated in the Northern Piedmont ecoregion. Nongovernmental organizations may also create "reserved" land through outright purchase or by partnering with local or state governments, and some claim to have set aside thousands of hectares (Figure 9). Many such organizations operate on the regional or county level within the ecoregion (see, for example, BC 2010; LFT 2010; MCLT 2010).

Reserved lands, however, are all subject to the impacts of development that is built around them, some of it drawn to the location because of the presence of the preserved areas (Geoghegan, Lynch, and Bucholtz 2003). Urban development is now encroaching on the Great Swamp National Wildlife Refuge, created to forestall the building of a major airport in the New Jersey portion of the ecoregion (Koch and Jensen 1999). Development has also increased in the immediate vicinity of other prominent public lands, including Valley Forge National Historical Park and Monocacy National Battlefield Park (outside Frederick, Maryland) (Figure 10).

The long-standing traditions of productive farming and cultural landscapes were also inhibitors of land change in the ecoregion. The Northern Piedmont has areas of extremely productive farms, and the inertia of long-standing agricultural traditions may have locally slowed land-use change during the study period. Robert Bielski found low to moderate new housing growth in Chester County, Pennsylvania, during the 1980 s in a group of municipalities that had "active agricultural activities and a strong open space preservation philosophy" $(1992,54)$. Chester County had also been a leader in mushroom growing, accounting for 20 percent of the national production by the early 1990s (Kelsey and Singletary 1996). The western half of Loudoun County had been part of the core of northern Virginia's horse farms and the traditional location of the county's political leadership (Gottmann 1969, 174; Frankel and Pae 1997). Lancaster County, Pennsylvania, had been a farming leader, ranking in the top twenty counties nationally in the value of agricultural products in 1997 and had also been the heartland of the Old Order Amish, a religious sect strongly associated with farming (Ericksen, Ericksen, and Hostetler 1980; NASS 1999).

A long-standing agricultural tradition and productive farms may offer only a transitory barrier to urban development, however. In Chester County the friction between mushroom farmers and new suburban and exurbanites, such as the smell of soil composting, increased between 1984 and 1994 (Kelsey and Singletary 1996). The political power in Loudoun County was shifting by the late 1990s, as the burgeoning population in the eastern half of the county gained more representation and expressed declining interest in maintaining traditional rural land use in the western half of the county at their expense (Frankel and Pae 1997). Lancaster County officials had stepped up agricultural land-preservation efforts in the 1990s, but development pressures, such as rising land prices, remained, and an increasing number of Amish families had moved from the county in a search for less hectic rural places (Testa 1992; Daniels 2000). The driving forces of land-use change in 


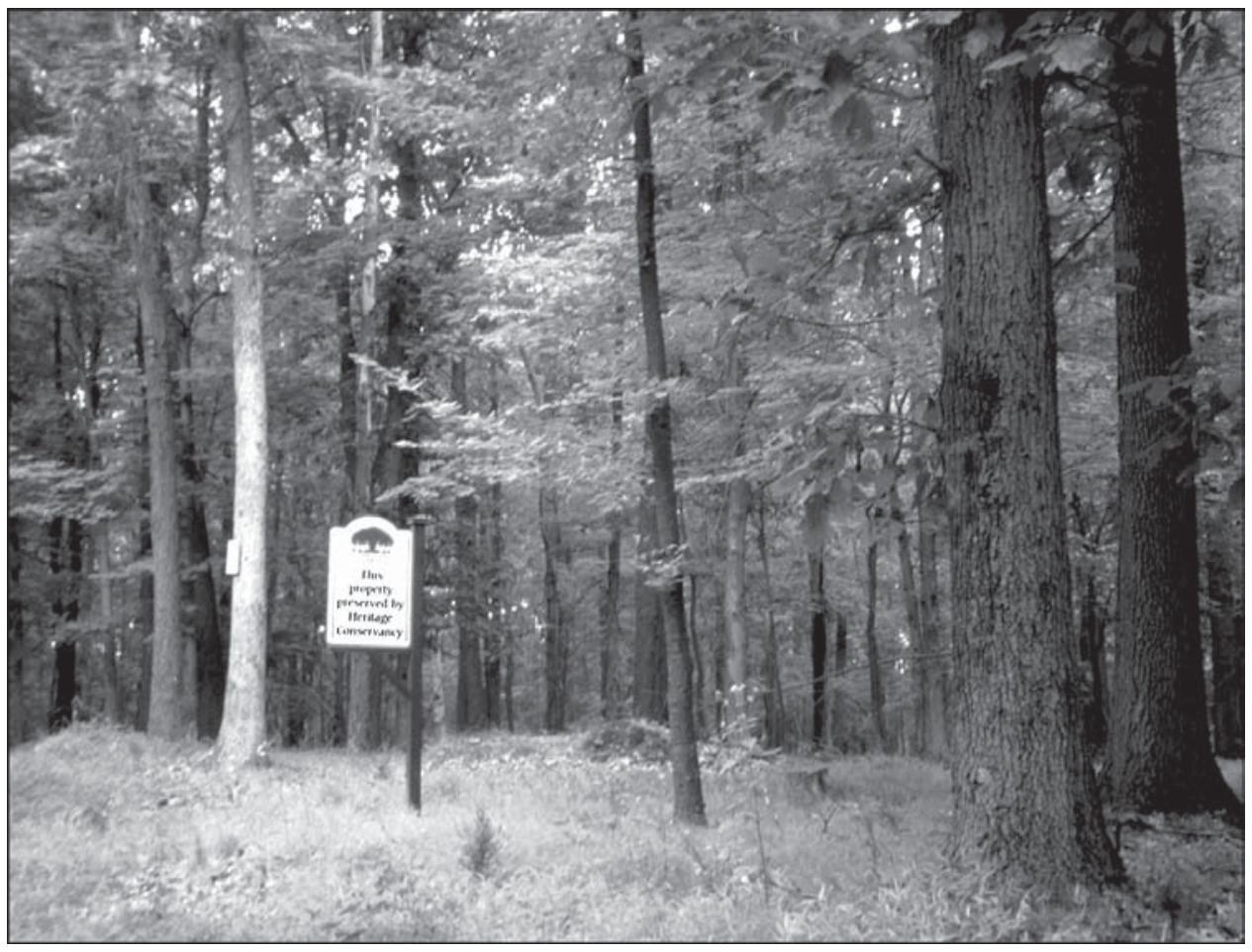

Fig. 9-A tract of forestland in Bucks County, Pennsylvania, reserved in 1985 by the Heritage Conservancy, a nongovernmental conservation organization. (Photograph by Roger Auch, August 2001)

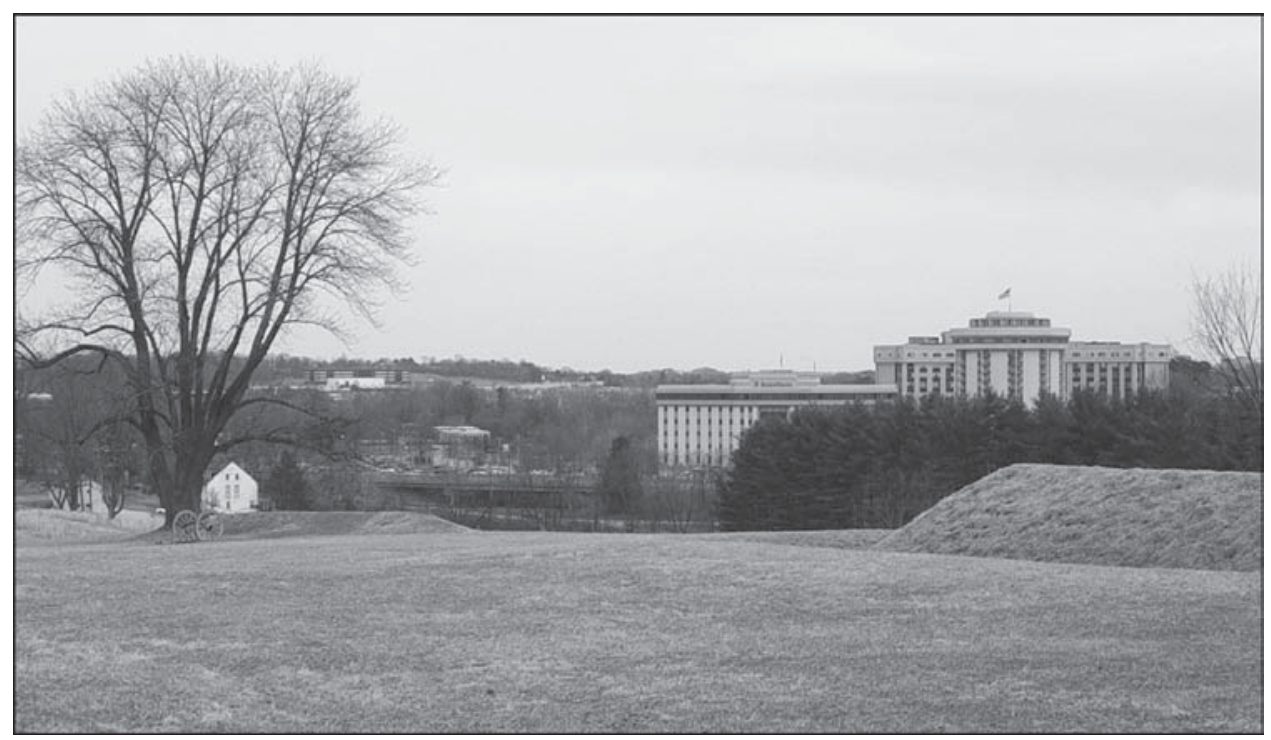

Fig. 10-An edge of Valley Forge National Historical Park that overlooks new development to the east. (Photograph by Roger Auch, March 2004) 
the ecoregion, as they themselves change, multiply, or intensify, may break down a strong agricultural tradition and productive farms, thus weakening them as inhibitors of change.

TEMPORAL DRIVING FORCES

Driving forces tend to ebb and flow as societal conditions change. Changing conditions provide landowners with different information on which to base their decisions and responses. For example, during times of recession new development typically declines and thus decreases the rate of land-cover change.

Two national events, having substantial impacts on land-use decisions but limited in time, affected Northern Piedmont land uses early in the study period. During the first half of the 1970s, the United States enjoyed a housing boom that was partially fueled by federally subsidized building loans (B. J. L. Berry 1980). The energy crises and a series of three recessions that occurred from 1973 through 1982 altered land-use decisions and subsequently reduced the demand for new housing (B. J. L. Berry 1980; Wood 1982).

Farmland is not normally competitive with developed uses, but when prices for farm products are high, farmers are more competitive. This situation existed briefly during the mid-to-late 1970s after a surge in the export demand for U.S. grain increased the value of farm products and resulted in farmland prices that increased faster than inflation. ${ }^{4}$ For several years farmland appeared to be a good investment (Healy and Short 1983), and the amount of agricultural land in the Northern Piedmont temporarily increased (Schertz 1979, 259-260; Auch 2002, 91). Conversely, the most active period of change occurred during the 1990s, when low oil prices, telecommunications expansion, high-technology growth, and the Internet boom fueled economic growth and land conversions (Walde and Dos Santos 2000; Auch 2002, 138-139).

Driving forces that are temporally limited are often difficult to measure, because dates of images and socioeconomic data may not coincide with the span of the ephemeral drivers. In the Land Cover Trends project, time intervals between image interpretations range from six to eight years. Some cyclic and short-term land changes may have occurred after one interpretation time and returned to their original category by the next. Also, a data-collection year will capture only a portion of a temporal event, perhaps when land changes are at the peak, the low, or in between. This is one reason why socioeconomic data are used to complement the land-change data collected from remotely sensed imagery, although non-imagebased data are not immune to the nature of temporal drivers.

\section{Lessons Learned and the Clashes of Externalities AND SCALES}

The conversions of agricultural and forest land to development were by far the most prevalent land changes in the Northern Piedmont ecoregion from 1973 to 2000. The rate of land-cover change was relatively steady for the first twenty years 
of the study period and then increased from 1992 to 2000. The most substantial forces driving the increase in developed land included an expanded highway system, a changing employment structure, a desire for rural exurban lifestyles, a changing housing supply, a changing population, indirect governmental policies, a decline in agricultural competitiveness and profitability, and an increasing "impermanence syndrome" in traditional rural land uses. The drivers that facilitated the change tended to reinforce one another. The synergy of multiple drivers, such as access to major highways, the location of new employment, and the location of newly built housing, for example, may be more important than any one individual driver of change. These combinations may comprise longer-lasting drivers or be associated with drivers that can suddenly change, such as changes in policy. Examples of the latter could be access to major highways, the location of new employment, and changed tax policy for new commercial construction.

Some of the driving forces in the Northern Piedmont, such as the energy crises and the three recessions that occurred from 1973 through 1982 or the economic boom of the 1990s, were ephemeral. The earlier temporal forces may have reduced the demand for land change, whereas the more recent forces tended to accelerate it. Other forces, such as agricultural preservation programs, opposition from local groups, and the presence of reserved lands, acted as stabilizers or inhibitors and thus tended to slow or prevent land-cover change.

The consequences of land-cover change in the Northern Piedmont may be a complex mix of both negative and positive externalities. This ecoregion, which has some of the most productive farmland on the East Coast of the United States, experienced agricultural land decline, along with losses in forest and overall open space. The spread of developed areas, especially low-density development, results in increased costs for additional public infrastructure. Increased vehicular emissions may result in deteriorating air quality. Increased urbanization has also covered more of the ecoregion's land with impervious surfaces that have affected the quality, quantity, and flow of water. Some of these negative consequences have affected neighboring regions, such as the Chesapeake Bay (Jantz, Goetz, and Jantz 2005).

On the other hand, many residents in the Northern Piedmont ecoregion found increased opportunities in newer and larger housing, employment, retail activities, and others ways to enjoy their lives. The desire of many people to live in less densely populated areas than did their recent ancestors, whether in a newer subdivision with larger lots, on an exurban parcel, or even on a hobby farm, appears to be quite strong. Approximately 41 percent of the counties and independent cities assigned to the Northern Piedmont had a higher percentage of children-18-yearolds and younger-than the national average in 2000. A subgroup of these, on the edge of the expanding metropolitan Washington, D.C., area in Virginia (LoudounPrince William-Manassas City), had a substantially lower median age compared with the national average (USCB 2003), meaning that portions of the ecoregion appear to be attractive to younger families. Contemporary land-cover change in 
the Northern Piedmont may have allowed many of the ecoregion's residents to live out parts of their American dream. Thus, land change produces a clash of externalities.

Future land-cover change in the Northern Piedmont will continue to be a clash of geographical scales or perspectives. Most change occurred at the individual or local scale, but its impacts, through accumulation, manifest themselves at a higher scale of the county, region, and nation. This clash of different scales leaves no easy solutions for the negative consequences of land change. Many of the driving forces discussed in this study will continue to exert their influence in the Northern Piedmont. Some forces may weaken and no longer affect land-cover change, and new, unforeseen forces may emerge to play a role. The greater understanding of driving forces of land change continues to be needed as we modify the world in which we live.

\section{Notes}

1. Four of these dates coincide with two large datasets that the Land Cover Trends project could access at no cost during the time of image interpretation. These were the North American Landscape Characterization and the UsGs National Land Cover Datasets. Only the circa 1980 imagery had to be purchased by the project.

2. The definition for developed land used by the UsGs Land Cover Trends project is, "Areas of intensive use with much of the land covered with structures (e.g. high density residential, commercial, industrial, transportation), or less intensive uses where the land-cover matrix includes both vegetation and structures (e.g. low density residential, recreational facilities, cemeteries, transportation and utility corridors, etc.), including any land functionally attached to the developed or built-up activity."

3. A county was assigned to the Northern Piedmont if a majority of its area was located within the ecoregion boundary.

4. For example, the amount of land used for growing corn for grain in the Northern Piedmont counties increased from 172,266 hectares in 1969 to a peak of 275,312 hectares in 1982. Hectares in corn for grain decreased in the 1980 os and 1990s, reaching a level of 169,221 hectares in 1997, slightly below the 1969 land area (USCB 1972-1994; NASS 1999).

\section{REFERENCES}

Adelaja, A., K. Sullivan, and Y. G. Hailu. 2011. Endogenizing the Planning Horizon in Urban Fringe Agriculture. Land Use Policy 28 (1): 66-75.

Auch, R. F. 2002. Land Use / Land Cover Change in the Northern Piedmont Ecoregion, 1970-2000. M.S. thesis, South Dakota State University.

Batie, S. S., and R. G. Healy. 1980. The Future of American Agriculture as a Strategic Resource. Washington, D.C.: Conservation Foundation.

BC [Brandywine Conservancy]. 2010. Environmental Management Center. [www.brandywineconservancy .org/index2.html].

Berry, B. J. L. 1980. Inner City Futures, an American Dilemma Revisited. Transactions, Institute of British Geographers, n.s., 5 (1): 1-28.

Berry, D. 1978. Effects of Urbanization on Agricultural Activities. Growth and Change 9 (3): 2-8.

Bielski, F. R. 1992. Population and Housing Trends. Chester County: The New Urban Frontier, 1980 to 1990. Pennsylvania Geographer 30 (1): 47-61.

Blum, J. 1998. WorldCom Plan Poses Question of County Costs: A Plum but at What Price? Washington Post, 24 May, §LE1o, 4. [www.highbeam.com/doc/1P2-661726.html].

CGCR [Committee on Global Change Research]. 1999. Global Environmental Change: Research Pathways for the Next Decade. National Research Council, Policy Division, Board of Sustainable Development, Committee on Global Change Research. Washington, D.C.: National Academy Press. 
Daniels, T. L. 1986. Hobby Farming in America: Rural Development or Threat to Commercial Agriculture? Journal of Rural Studies 2 (1): 31-40.

- 2000. Integrated Working Landscape Protection: The Case of Lancaster County, Pennsylvania. Society and Natural Resources 13 (3): 261-271.

Danielson, M. N., and J. Wolpert. 1992. Rapid Metropolitan Growth and Community Disparities. Growth and Change 23 (4): 494-515.

DiLisio, J. E. 1983. Maryland: A Geography. Boulder, Colo.: Westview Press.

Drummond, M. A., and T. R. Loveland. 2010. Land-Use Pressure and a Transition to Forest-Cover Loss in the Eastern United States. BioScience 60 (4): 286-298.

Ericksen, E. P., J. A. Ericksen, and J. A. Hostetler. 1980. The Cultivation of the Soil as a Moral Directive: Population Growth, Family Ties, and the Maintenance of Community among the Old Order Amish. Rural Sociology 45 (1): 49-68.

Erickson, R. A., and M. Gentry. 1985. Suburban Nucleations. Geographical Review 75 (1): 19-31.

Fehr, S. C. 1997. Montgomery's Line of Defense against the Suburban Invasion. Washington Post, 25 March, $\$ A, 1$.

Frankel, G., and P. Pae. 1997. In Loudoun, Two Worlds Collide. Washington Post, 24 March, §A, 1.

Friedman, S., A. Singer, M. Price, and I. Cheung. 2005. Race, Immigrants, and Residence: A New Racial Geography of Washington, D.C. Geographical Review 95 (2): 210-230.

Fulton, W. 1986. Silicon Strips. Planning 52 (5): 7-12.

Gallant, A. L., T. R. Loveland, T. L. Sohl, and D. E. Napton. 2004. Using an Ecoregion Framework to Analyze Land-Cover and Land-Use Dynamics. Environmental Management 34 (Supplement 1) S89-S110.

Garreau, J. 1991. Edge City: Life on the New Frontier. New York: Doubleday.

Geoghegan, J., L. Lynch, and S. Bucholtz. 2003. Capitalization of Open Spaces into Housing Values and the Residential Property Tax Revenue Impacts of Agricultural Easement Programs. Agricultural and Resource Economics Review 32 (1): 33-45.

GeoLytics. 1999. Census CD+ Maps. New Brunswick, N.J.: GeoLytics.

Giordano, C., and F. Schnidman. 1979. Agricultural Preservation in Montgomery County, Maryland. Journal of Soil and Water Conservation 34 (5): 207-210.

Gober, P. 1981. Falling Household Size and Its Effect on Metropolitan Population Growth and Density. Annals of Regional Science 15 (3): 1-10.

Goldstein, M. 1995. Migration Patterns for Maryland and Its Jurisdictions, 1980-1992. [Baltimore]: Maryland Office of Planning.

Gottmann, J. 1959. Revolution in Land Use. Landscape 8 (2): 15-21.

- 1961. Megalopolis: The Urbanized Northeastern Seaboard of the United States. New York: Twentieth Century Fund.

- 1969. Virginia in Our Century. Charlottesville: University Press of Virginia.

Gustanski, J. A., and R. H. Squires, eds. 2000. Protecting the Land: Conservation Easements Past, Present, and Future. Washington, D.C.: Island Press.

Hanson, M. E. 1992. Automobile Subsidies and Land Use: Estimates and Policy Responses. Journal of the American Planning Association 58 (1): 60-71.

Hart, J. F. 1991a. The Land That Feeds Us. New York: W. W. Norton. . 1991b. The Perimetropolitan Bow Wave. Geographical Review 81 (1):35-51.

Hartmann, J. R., and J. H. Goldstein. 1994. The Impact of Federal Programs on Wetlands, vol. 2, The Everglades, Coastal Louisiana, Galveston Bay, Puerto Rico, California's Central Valley, Western Riparian Areas, Southeastern and Western Alaska, The Delmarva Peninsula, North Carolina, Northeastern New Jersey, Michigan, and Nebraska. Washington, D.C.: U.S. Department of the Interior.

Healy, R. G., and J. L. Short. 1983. Changing Markets for Rural Lands: Patterns and Issues. In Beyond the Urban Fringe: Land Use Issues of Nonmetropolitan America, edited by R. H. Platt and G. Macinko, 109-134. Minneapolis: University of Minnesota Press.

Herbers, J. 1986. The New Heartland: America's Flight Beyond the Suburbs and How It's Changing Our Future. New York: Times Books.

Jackson, K. T. 1985. Crabgrass Frontier: The Suburbanization of the United States. New York: Oxford University Press.

Jakle, J. A., and D. Wilson. 1992. Derelict Landscapes: The Wasting of America's Built Environment. Savage, Md.: Rowman \& Littlefield. 
Jantz, P., S. Goetz, and C. Jantz. 2005. Urbanization and the Loss of Resource Lands in the Chesapeake Bay Watershed. Environmental Management 36 (6): 808-825.

Kelsey, T. W., and L. Singletary. 1996. Conflict at the Rural/Urban Interface: Mushroom Farms and Composting in a Suburbanizing Environment. Compost Science \& Utilization 4 (3): 89-96.

Koch, B., and L. Jensen. 1999. A Partnership Grows in the Great Swamp. U.S. Fish and Wildlife Service, Ecological Services, New Jersey Field Office. Formerly at [www.fws.gov/northeast/njfieldoffice /Publications Holding/MAY 1999/fn599p9.html].

Lang, R., and P. K. Knox. 2009. The New Metropolis: Rethinking Megalopolis. Regional Studies 43 (6): $789-802$.

Layton, R. 1980. Hobby Farming. Geography 65 (3): 220-224.

Levinson, D. 1997. The Limits to Growth Management: Development Regulation in Montgomery County, Maryland. Environment and Planning B: Planning and Design 24 (5): 689-707.

Lewis, P. 1995. The Urban Invasion of Rural America: The Emergence of the Galactic City. In The Changing American Countryside: Rural People and Places, edited by E. N. Castle, 39-62. Lawrence: University Press of Kansas.

LFT [Lancaster Farmland Trust]. 2010. Land Preservation Services. Lancaster Farmland Trust. [http: //lancasterfarmlandtrust.org/home/preservation.html].

Lockeretz, W., J. Freedgood, and K. Coon. 1987. Farmers' Views of the Prospects for Agriculture in a Metropolitan Area. Agricultural Systems 23 (1): 43-61.

Lopez, R. A., A. O. Adelaja, and M. S. Andrews. 1988. The Effects of Suburbanization on Agriculture. American Journal of Agricultural Economics 70 (2):346-358.

Loveland, T. R., T. L. Sohl, S. V. Stehman, A. L. Gallant, and others. 2002. A Strategy for Estimating the Rates of Recent United States Land-Cover Changes. Photogrammetric Engineering \& Remote Sensing 68 (10): 1091-1099.

Lynch, L. 2009. Land Preservation Programs Achieve High Levels of Efficiency. American Journal of Agricultural Economics 91 (5): 1368-1374.

Mather A. S. 1992. The Forest Transition. Area 24 (4): 367-379.

Mather A. S., and C. L. Needle. 1998. The Forest Transition: A Theoretical Basis. Area 30 (2): 117-124.

MCLT [Montgomery County Lands Trust]. 2010. Open Space Success Stories. Montgomery County [Pennsylvania] Lands Trust. [www.mclt.org/openspaces/stories.htm].

Meyer, W. B., and B. L. Turner II. 1994. Changes in Land Use and Land Cover: A Global Perspective. New York: Cambridge University Press.

Miller, E. W. 1995. Manufacturing. In A Geography of Pennsylvania, edited by E. W. Miller, 252-284. University Park: Pennsylvania State University Press.

Moe, R., and C. Wilkie. 1997. Changing Places: Rebuilding Community in the Age of Sprawl. New York: Henry Holt.

Morrill, R. 1992. Population Redistribution Within Metropolitan Regions in the 1980s: Core, Satellite, and Exurban Growth. Growth and Change 23 (3): 277-302.

- 2006. Classic Map Revisited: The Growth of Megalopolis. Professional Geographer 58 (2): $155-160$.

Napton, D., and T. Loveland. 2004. U.S. Land Use and Land Cover Change: 1973-2000. In WorldMinds: Geographical Perspectives on 100 Problems, edited by D. G. Janelle, B. Warf, and K. Hansen, 261266. Dordrecht, Netherlands: Kluwer Academic Publishers.

Napton, D. E., R. F. Auch, R. Headley, and J. L. Taylor. 2010. Land Changes and Their Driving Forces in the Southeastern United States. Regional Environmental Change 10 (1): 37-53.

NASS [National Agricultural Statistics Service]. 1999. 1997 Census of Agriculture. Vol. 1, Geographic Area Series, county data. Washington, D.C.: U.S. Department of Agriculture.

NJDEP [New Jersey Department of Environmental Protection]. 2010. Green Acres Program. New Jersey Department of Environmental Protection. [www.nj.gov/dep/greenacres].

Ojima, D. S., K. A. Galvin, and B. L. Turner II. 1994. The Global Impact of Land-Use Change. BioScience 44 (5): 300-304.

Omernik, J. M. 1987. Ecoregions of the Conterminous United States. Annals of the Association of American Geographers 77 (1): 118-125.

R50CC [Route 50 Corridor Coalition]. 2011. Route 50 Traffic Calming History. Route 50 Corridor Coalition. [http://route50.org/rt5otrafficcalm.html].

Schertz, L. P. 1979. The Northeast. In Another Revolution in U.S. Farming?, edited by L. P. Schertz, 257276. Washington, D.C.: U.S. Government Printing Office. 
Short, J. R. 2007. Liquid City: Megalopolis and the Contemporary Northeast. Washington, D.C.: RFT Press.

Sleeter, B. M., T. S. Wilson, C. E. Soulard, and J. Liu. 2011. Estimation of Late Twentieth Century Land-Cover Change in California. Environmental Monitoring and Assessment 173 (1-4): 251-266.

Smith, K. 1999. Southeastern Pennsylvania: Can Agriculture Be Sustained? In Under the Blade: The Conversion of Agricultural Landscapes, edited by R. K. Olson and T. A. Lyson, 287-294. Boulder, Colo.: Westview Press.

Sohl, T. L., and L. Sohl. In press. Land Use Change in the Atlantic Coastal Pine Barrens Ecoregion. Geographical Review.

SPC [State Planning Commission]. 2004. Preserving Delaware. Delaware Office of State Planning Coordination. Formerly at [http://stateplanning.delaware.gov/strategies/document_04 /o6_preserving.pdf].

Tavernier, E. M., and V. Tolomeo. 2004. Farm Typology and Sustainable Agriculture: Does Size Matter? Journal of Sustainable Agriculture 24 (2): 33-46.

Testa, R.-M. 1992. After the Fire: The Destruction of the Lancaster County Amish. Hanover, N.H.: University Press of New England.

Theobald, D. M. 2001. Land-Use Dynamics Beyond the American Urban Fringe. Geographical Review 91 (3): $544-564$.

USBLS [U.S. Bureau of Labor Statistics]. 2001. Covered Workers and Wages (ES-202). Formerly at [http://databls.gov/labjava/outside.jsp?survey=ew].

USCB [U.S. Census Bureau]. 1972-1994. Census of Agriculture. Vol. 1, Geographic Area Series, county data. Washington, D.C.: Bureau of the Census.

__ _ 1973. 1970 Census of Population. Vol. 1, Characteristics of the Population, table 123. [www.census.gov/prod/www/abs/decennial/1970.html].

- 1993. 1990 Census of Population. CP-2, Social and Economic Characteristics, table 146. [www.census.gov/prod/www/abs/decennial/199o.html].

- 2003. 2000 Census of Population and Housing. Summary Files $3\left(\mathrm{SF}_{3}\right)$ and 4 ( $\left.\mathrm{SF}_{4}\right)$. Formerly at [http://factfinder.census.gov].

Vincino, T. J., B. Hanlon, and J. R. Short. 2007. Megalopolis 50 Years On: The Transformation of a City Region. International Journal of Urban and Regional Research 31 (2): 344-367.

Vitousek, P. M., H. A. Mooney, J. Lubchenco, and J. M. Melillo. 1997. Human Domination of Earth's Ecosystems. Science 277 (5325): 494-499.

Walde, T., and E. Moutinho Dos Santos. 2000. Comments on the Ups (and Past and Future Downs) of the Oil Price. Revue de L'Energie 51 (520): 453-459.

Wear, D. N., R. Liu, J. M. Foreman, and R. M. Sheffield. 1999. The Effects of Population Growth on Timber Management and Inventories in Virginia. Forest Ecology and Management 118 (1-3): 107-115.

Wells, B. 2001. Smart Growth Programs: Governors' Smart Growth Initiatives. Washington, D.C.: Northeast-Midwest Institute. Formerly at [www.nemw.org/Gov_sgi.pdf].

Wood, L. J. 1982. Consumer Behaviour and Energy Supply. Australian Geographical Studies 20 (1): $108-115$.

Zelinsky, W. 1995. Cultural Geography. In A Geography of Pennsylvania, edited by E. W. Miller, 132153. University Park: Pennsylvania State University Press. 